Research Article

\title{
A path analysis of the relation between study habit and students' academic achievement
}

\author{
Erik Prasetyo a,1, Saiful Ridlo a,2,", Nugroho Edi Kartijono a,3 \\ a Biology Education Study Program, Biology Department, Mathematic and Natural Science Faculty, Universitas Negeri Semarang, \\ Kampus Sekaran Gunungpati, Semarang, 50229, Indonesia \\ 1 erikprasetyo96@gmail; 2 saiful_ridlo@mail.unnes.ac.id *; 3 nugrohoedik@mail.unnes.ac.id \\ ${ }^{*}$ Corresponding author
}

\begin{tabular}{|c|c|}
\hline ARTICLE INFO & ABSTRACT \\
\hline $\begin{array}{l}\text { Article history } \\
\text { Received March 15, } 2019 \\
\text { Revised June 26, } 2019 \\
\text { Accepted June 28, } 2019 \\
\text { Published July 10, } 2019 \\
\text { Keywords } \\
\text { Academic achievement } \\
\text { Attending lectures } \\
\text { Facing examination } \\
\text { Reading books } \\
\text { Visiting library }\end{array}$ & $\begin{array}{l}\text { Study habit (attending lectures, reading books, visiting library, and facing examination) } \\
\text { plays an important role in determining academic achievement. The objectives of this } \\
\text { study were to analyze the correlation between study habits and academic achievement, } \\
\text { and analyze the indicators that were most significantly correlated with students' academic } \\
\text { achievement. The study was conducted at the Biology Department of FMIPA UNNES in } \\
\text { February - March 2018. The sample of respondents consisted of students of the Biology } \\
\text { Department of academic years } 2014,2015 \text { and } 2016 \text {. A total of } 308 \text { students were taken } \\
\text { as the sample using proportional stratified random sampling technique. The data was } \\
\text { taken using a questionnaire instrument and analyzed using the path analysis method } \\
\text { assisted by SmartPLS. The results of the data analysis showed that the indicators of } \\
\text { study habit have a significant correlation to the students' academic achievement of } \\
\text { Biology Department. The correlation coefficient values of study habit indicators from high } \\
\text { to low were reading books, attending lectures, facing exams, and visiting the library. This } \\
\text { study showed that the habit of reading books had the most significant correlation. It is } \\
\text { suggested to conduct the experimental research which is related to the effectiveness of } \\
\text { reading habit. }\end{array}$ \\
\hline
\end{tabular}

How to cite: Presetyo, E., Ridlo, S., \& Kartijono, N.E. (2019). A path analysis of the relation between study habit and students' academic achievement. JPBI (Jurnal Pendidikan Biologi Indonesia), 5(2), 297-304. doi: https://doi.org/10.22219/jpbi. v5i2.7884

\section{INTRODUCTION}

Academic achievement can be influenced by factors that come from within students (internal) and from outside (extern). Factors from within include psychological factors and physiological factors, while from outside include environmental factors and instrumental factors. Psychological factors that have a large influence on academic achievement are study habits. Poor study habits can be a major factor in the failure to achieve academic achievement. Good study habits include being organized, keeping good notes, reading your textbooks, listening in class, and working every day (Verma, 2016). Good study habits include four indicators, there are the habits of attending lectures, reading books, visiting the library and facing exams (Akpan \& Salome, 2015; Eamin, Akanda, \& Haque, 2013; Khong, Dunn, Lim, \& Yap, 2016; Ogunduyilemi, 2018). The question is whether there is a significant correlation between the four indicators of study habits with student achievement, and what indicator have the biggest contribution to student achievement. 
Good study habits are closely related to the use of the time that is good for learning and other activities. That efficient learning can be achieved when using the right strategy, there is the existence of a good time setting in attending lectures, studying at home, studying independently or in groups, and in taking exams. Good study habits can be realized if students are aware of their responsibilities as students so that they can divide their time well between learning and activities outside of learning (Wulandari's, 2014). The results of the study about the influence of study habits on the academic achievement showed that only two indicators of study habits had a significant effect (attending lectures and visiting the library) on students' academic achievement (Aquino, 2011; Manurung, 2017; Numan \& Hasan, 2017; Sherafat \& Murthy, 2016).

In real situations, students in some cases had negative behavior. The phenomenon that often occurs was that students were very dependent on the lecturers about the lectures' material. During the lectures, students did not pay attention to lectures, playing mobile phones, laptops, talking to friends, and others. Students also rarely go to the library, visiting only when there were assignments. Lack of preparation if only study when during the exam. Research studies on study habits have not been carried out in the Biology Education Study Program Faculty of Mathematics and Natural Sciences Universitas Negeri Semarang. These study habits were possible to influence students' academic achievement. Then Biology Education Study Program can apply the best learning method (one or few methods) to increasing the study habits and hope the academic achievement will increase too.

Study habits are how one studies. Theoretically, study habits are closely related to student academic achievement and performance (Alva, 2017; Ebele \& Olofu, 2017; Obadara \& Olaopa, 2018; Magulod, 2019). Good study habits that will influence the better academic achievement of students. Variable study habits are not single jobs improving academic achievement. Learning styles, learning strategies, learning activities, promotion of student participation, literacy and attitude, learning centers are various variables that work together to influence academic achievement (Üzüm \& Pesen, 2018; Alburaidi \& Ambusaidi, 2019; Salvo, Welch \& Shelton, 2019; Kumaraswamy, 2019).

Study habits have been studied for a long time, though in the last five years there have been many studies from various angles of study. A few researchers focused on examining the dimensions of the constructs of learning habits. Reading habits as one dimension have been studied (Eamin et al., 2013; Rodrigo, Greenberg, \& Segal, 2014; Sengul, 2017). Research on the relationship between study habits and academic achievement has been carried out by Goel (2015) using Study Habits Inventory (SHI) instruments and Nadeem, Puja, and Bhat, (2014) using the Palsane \& Sharma Study Habits Inventory (PSSHI) instrument but both did not attempt to find dimensions/indicators that most influence academic achievement. Meanwhile, Kaur and Pathania, (2015) studied the dimensions of learning habits with the exploratory method. The dimensions of learning habits that they both learn are home environment \& planning, habits \& attitude, and the college environment. In this study, the dimensions and indicators of study habits were studied using confirmatory analysis, namely the path analysis method

The absence of information about student learning habits causes the study program manager to be less than perfect in evaluating academic achievement. There have been limited studies concerned on psychological factor about study habits of Biology Education students. Therefore, this research intends to know their study habits more detail and their influence on academic achievement. The objectives of the study are to analyze the relationship between student learning habits and academic achievement and find the most significant dimensions correlated with academic achievement. The results of this study were useful to determine the relationship of each indicator of study habits towards student academic achievement. Also, be used as material for consideration in determining appropriate actions to improve student academic achievement.

\section{METHOD}

This study was conducted at Biology Department-Mathematic and Natural Science Faculty, Universitas Negeri Semarang (FMIPA UNNES) in February - March 2018. This study used a quantitative descriptive approach (Suharsimi, 2010). The population in this study included all students of Biology Education Study Program FMIPA UNNES class of 2014, 2015 and 2016. Determination of the number of samples used Slovin techniques and sampling techniques used proportional stratified random sampling technique. The number of samples in this study was 174 students.

Collecting data in the study used study habits' questionnaire with 50 items of statements. The questionnaire includes four dimensions of study habits, there was the habit of attending lectures (X1), the habit of reading books (X2), the habit of visiting the library (X3) and the habit of facing exam X4). Data of academic achievement (Y) was obtained by conducting a study of documentation to the Biology Education Study Program. 
The analysis technique used in this research was path analysis with the approach partial least square (PLS) with the help of Smart PLS version 2.0 software. Path analysis consists of several stages, that was the goodness of fit outer model test, the goodness of fit inner model test, and model stability test. Analysis of the goodness of fit outer model (measurement model) was evaluated using convergent validity, discriminant validity, and composite reliability. Analysis of the goodness of the inner fit model (structural model) was evaluated using the $\mathrm{R}$-square and Q-square value of predictive relevance. The stability of these estimates was evaluated using the t-test obtained through the procedure bootstrapping with t-statistic 1.97 and alpha 0.05 .

\section{RESULTS AND DISCUSSION}

Based on the results of the evaluation of the goodness of fit outer model, it was found that the models used were valid and reliable (Table 1). This evaluation was carried out by partial least square (PLS) algorithm. The value of convergent validity based on the loading factor showed the value that meets the rule of thumb $>0.5)$. The value of discriminant validity showed that the AVE and root of AVE comparison values meet the rule of thumb (AVE value $>0.5$ and root of AVE $>A V E$ ). The composite reliability value showed that the model meets the rule of thumb $(>0.7)$.

Table 1. Evaluation results of the goodness of fit outer model of

\begin{tabular}{|c|c|c|c|c|c|}
\hline \multirow[b]{2}{*}{ No } & \multirow[b]{2}{*}{ Indicator } & \multirow{2}{*}{$\begin{array}{c}\text { Convergent } \\
\text { Validity }\end{array}$} & \multicolumn{2}{|c|}{ Discriminant Validity } & \multirow[b]{2}{*}{ Composite Reliability } \\
\hline & & & AVE Value & The roof of AVE Value & \\
\hline 1. & The Habit of Attending Lectures & 0,71113363 & 0,517218 & 0,719178 & 0,961744 \\
\hline 2. & The Habit of Reading Book & 0,72870790 & 0,534567 & 0,731140 & 0,919414 \\
\hline 3. & The Habit of Visiting Library & 0,71995256 & 0,507207 & 0,712184 & 0,902036 \\
\hline 4. & The Habit of Facing Exam & 0,72067343 & 0,527171 & 0,726065 & 0,884912 \\
\hline 5. & Academic Achievement & 1,00000000 & 1,000000 & 1,000000 & 1,000000 \\
\hline
\end{tabular}

Based on the evaluation of the inner goodness of fit the model showed good results. The R-square value was 0.363 indicates that the goodness of the formation of the model from the study of academic achievement can be explained quite well by the indicators of study habits of $36.3 \%$. This value showed that study habits account for $36.3 \%$ in determining student learning achievement, while $63.7 \%$ of academic achievement was determined by other variables outside of research. According to Irhas, Sumadi and Ridlo, (2018) these variables may be learning styles, learning strategies, learning activities, promotion of student participation, literacy and attitude, and learner-centered. The calculation Q-square obtained a value of 0.131 indicating a value greater than 0 . This proves that the study habit indicators -nested inside each dimension- had a good level of prediction on student academic achievement.

Testing the magnitude of the relationship between dimensions/indicators of study habits on student academic achievement in Biology Education Study Program based on the value of the correlation coefficient. The correlation coefficient was obtained from the results of the analysis of a PLS algorithm. The results of testing with the PLS algorithm can be seen in Table 2.

Table 2. Results of tests with the PLS algorithm

\begin{tabular}{cc}
\hline Dimension & Values of Correlation Coefficient \\
\hline X1 & 0.236 \\
X2 & 0.272 \\
X3 & 0.189 \\
X4 & 0.208 \\
\hline
\end{tabular}

The results indicate a relationship or correlation of study habit's indicators and academic achievement. The habit of reading books had the most significant correlation. The habit of attending lectures, visiting libraries and facing examinations had a very weak correlation with student academic achievement. The level of the correlation coefficient from high to low is the habit of reading books, the habit of attending lectures, the habit of facing exams and the habit of visiting the library. For more details, the construction results of the path diagram PLS algorithm can be seen in Figure 1.

Correlation of each study habit's indicators was supported by results of the bootstrapping test which showed significant influence. This was evidenced by the t-value of each indicator having a higher value than the tstatistic value (Table 3). The t-statistic value in this study was 1.97 . 


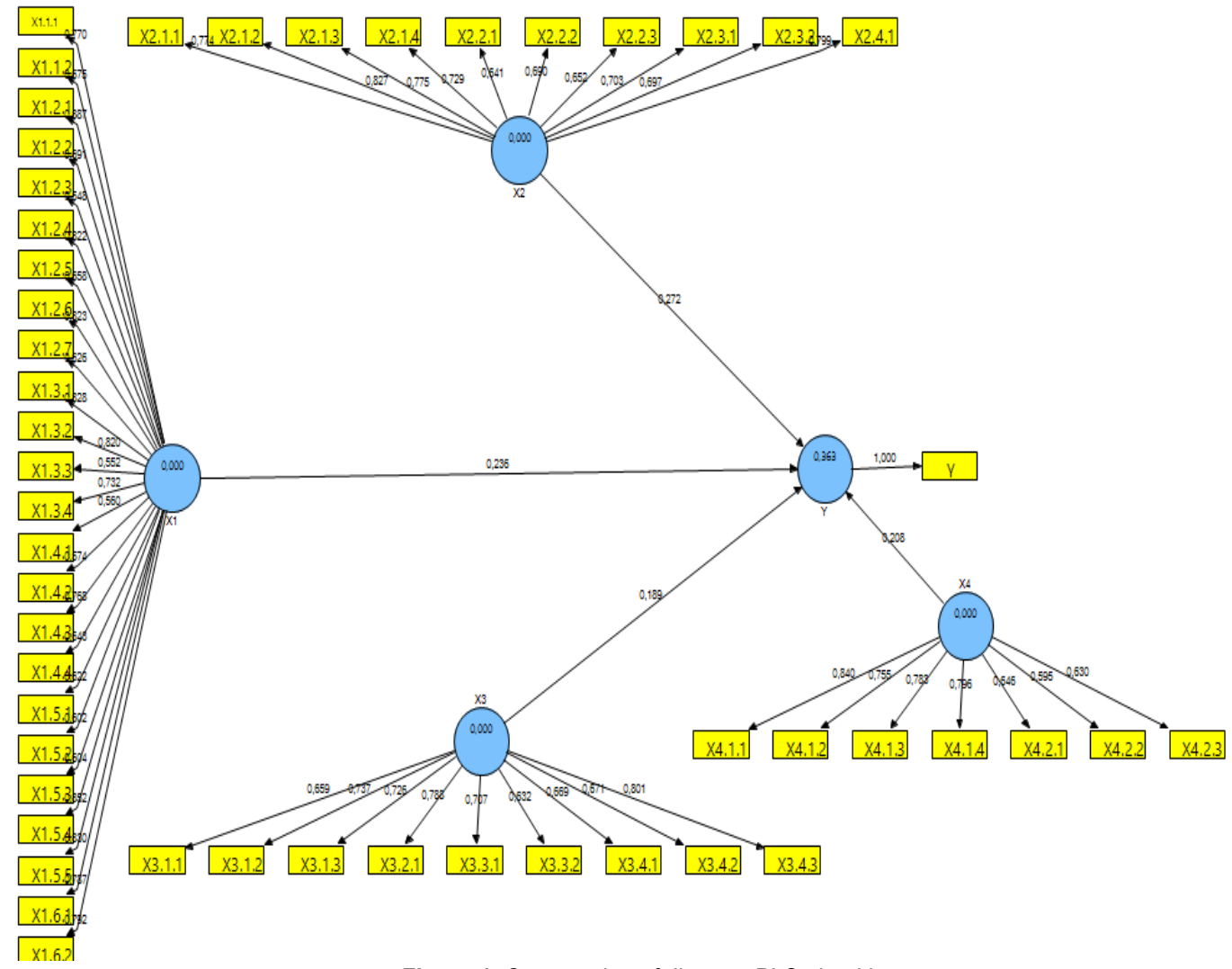

Figure 1. Construction of diagram PLS algorithm output

Table 3. Test results with bootstrapping SmartPLS

\begin{tabular}{|c|c|c|c|c|c|c|}
\hline No & Indicator & $\begin{array}{c}\text { Original } \\
\text { Sample (0) }\end{array}$ & $\begin{array}{c}\text { Sample } \\
\text { Mean (M) }\end{array}$ & $\begin{array}{c}\text { Standard } \\
\text { Deviation (STDEV) }\end{array}$ & $\begin{array}{l}\text { Standard Error } \\
\text { (STERR) }\end{array}$ & $\begin{array}{c}\text { T Value } \\
(\mid \text { O/STERR } \mid)\end{array}$ \\
\hline 1. & $\begin{array}{l}\text { The Habit of Attending } \\
\text { Lectures Academic } \\
\text { Achievement }\end{array}$ & 0,235521 & 0,237592 & 0,066974 & 0,066974 & 3,516619 \\
\hline 2. & $\begin{array}{l}\text { The Habit of Reading Book } \\
\text { Academic Achievement }\end{array}$ & 0,271956 & 0,274499 & 0,063757 & 0,063757 & 4,265525 \\
\hline 3. & $\begin{array}{l}\text { The Habit of Visiting Library } \\
\text { Academic Achievement }\end{array}$ & 0,188536 & 0,191009 & 0,067079 & 0,067079 & 2,810677 \\
\hline 4. & $\begin{array}{l}\text { The Habit of Facing Exam } \\
\text { Academic Achievement }\end{array}$ & 0,208064 & 0,221548 & 0,052348 & 0,052348 & 3,974599 \\
\hline
\end{tabular}

Based on the results test indicates a significant difference between the study habits and academic achievement. Poor study habit was a major cause of good academic achievement. According to Boehler et al., (2001) in his study found a positive and significant correlation between study habits and academic achievement. Students who had a habit of making important notes (by reading and marking important things in books and lecture notes, and making important notes on all books that are read) in their learning had better academic achievements than those who don't.

Showed a significant influence between study habits and academic achievement. This showed that if study habits, then the academic achievement will also increase. That good academic achievement was balanced with good study habits, while poor academic achievement was also influenced by poor study habits (Aquino, 2011; Dano, 2017; Monica, 2015). In the study of Kaur and Pathania (2015) showed that the most correlated indicator was the habit of attending lectures. In this research showed that the most significant value was the habit of attending lectures. But Sakirudeen and Sanni (2017) showed different results, that was the habit of visiting the library (aspects of leisure time and library use) has the most significant correlation.

The habit of reading books had the highest correlation coefficient compared to other indicators which are 0.272 included in the fairly strong category (Figure 2). This showed that the level the habit of reading books from student respondents was very influential in their academic achievement. That reading habits in high school students were very influential in determining their academic achievement. 


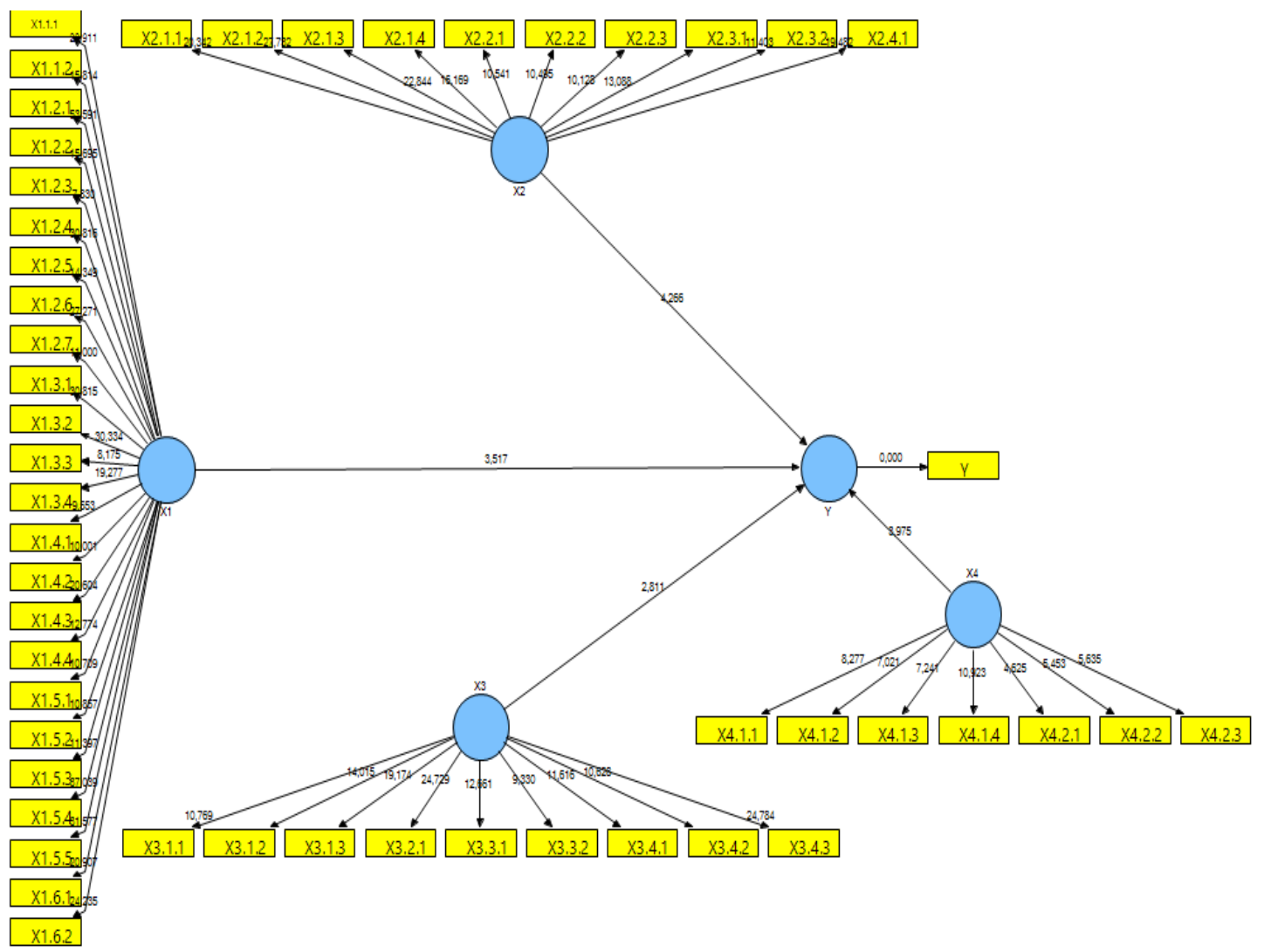

Figure 2. Construction research model by bootstrapping

In this study showed different results with the previous research, that was reading books had the most significant in determining academic achievement. According to Fitriah, (2017) reading activities include the prereading stage, the reading stage, and the post-reading stage. Each of these stages includes different activities. The pre-reading stage is intended to increase the motivation to read and activate the schemata owned by the reader. The activity of activating the schemata is useful to increase the reader's understanding of the reading material and to build new knowledge. The understanding process will be hampered if the reader schemata are not prepared beforehand. In accordance with Nurgiyantoro, (2004) revealed that the success of the study was largely determined by the ability and willingness to read it. The ability and willingness to read will greatly affect the views about various problems.

According to Wulandari, (2014) there are several factors affect learning achievement. Examples of factors originating from within a student (internal) are learning motivation and learning behavior, while examples of factors originating from outside a student's self (external) are learning models. Learning motivation can arise inside or outside. The motivation that arises from within a student will be more stable and stable when compared to motivation that arises because of outside influences. Students who have high motivation in learning tend to be more active in efforts to improve their achievement. In accordance with Fitriah (2017) reveals that the high ability to read book was very important to balance the flow of information that was increasingly heavy in various lives today.

Components of the habit of reading books in this study had been shown to increase academic achievement. The component includes the activity of preparing lecture material, understanding reading, reading recommended textbooks and reading other textbooks. The components of preparing lecture materials include the preparation of lecture materials, reading lecture material, repeating reading and supporting activities. The component of reading comprehension showed that understanding reading will help students build knowledge and memories related to lecture material. The component of reading the book above can help students develop their knowledge to achieve good learning achievement. The component of reading other textbooks can broaden the knowledge needed by students to improve their achievements (Berry, Cook, Hill, \& Stevens, 2010).

According to Wulandari, (2014) learning achievement is essentially a reflection of learning efforts, the better the effort to learn the better the achievements. Academic achievement achieved by a student is the result of interaction between various factors that influence it, both from within (internal) and from outside students 
(external factors). An introduction to the factors that influence academic achievement is needed to understand how changes in determinants are related to changes in achievement so that ultimately it becomes a recommendation for policymaking in accounting education. In accordance with Manurung, (2017) learning behavior has a positive and significant effect on academic achievement. this shows that learning behavior that is getting better and improved will increase students' academic achievement

Based on the description, the variable study habits of students in reading books can be used as a reference for stakeholders in taking implementing policies to maintain and or improve student achievement in Biology Education Study Program FMIPA UNNES.

\section{CONCLUSION}

Study habits (habit of attending lectures, reading books, library visiting, and facing exams) had a significant effect on students' academic achievement in Biology Education Study Program FMIPA UNNES. The highest correlated indicator of study habits was the habit of reading books with a correlation coefficient of 0.272 . Suggestion to conduct experimental research related to the effectiveness of reading (books, articles of national and international journals, monographs, etc.) habit to increase the students' academic achievement.

\section{ACKNOWLEDGMENT}

Acknowledge to all students of 2014, 2015 and 2016 Biology Education Study Program-Mathematic and Natural Science Faculty, Universitas Negeri Semarang (FMIPA UNNES) and lectures of the Biology Department FMIPA UNNES.

\section{REFERENCES}

Akpan, N. A., \& Salome, E. (2015). Effect of study habit on academic achievement of agricultural science students in senior secondary schools in emohua local government area of rivers state, Nigeria. International Journal of Education and Evaluation, 1(8), 118-125. Retrieved from https:/liiardpub.org/get/ IJCCPNOL 1/118-125.pdf

Alburaidi, A., \& Ambusaidi, A. (2019). The impact of using activities based on the montessori approach in science in the academic achievement of fourth grade students. International Journal of Instruction, 12(2), 695-708. doi: https://doi.org/10.29333/iji.2019.12244a

Alva, M. L. C. (2017). Self-esteem, study habits and academic performance among university students. Journal of Educational Psychology, 5(1), 71-127. doi: https://doi.org/10.20511/pyr2017.v5n1.145

Aquino, L. B. (2011). Study habits and attitudes of freshmen students: implications for academic intervention programs. Journal of Language Teaching and Research, 2(5), 1116-1121. doi: https://doi.org/10.4304/jttr. 2.5.1116-1121

Berry, T., Cook, L., Hill, N., \& Stevens, K. (2010). An exploratory analysis of textbook usage and study habits: misperceptions and barriers to success. College Teaching, 59(1), 31-39. doi: https://doi.org/10.1080/875 67555.2010 .509376

Boehler, M. L., Schwind, C. J., Folse, R., Dunnington, G., Markwell, S., \& Dutta, S. (2001). An evaluation of study habits of third-year medical students in a surgical clerkship. American Journal of Surgery, 181(3), 268-271. doi: https://doi.org/10.1016/S0002-9610(01)00569-4

Dano, J. C. (2017). Learning styles, study habits and academic performance of nursing students. The Malaysian Journal of Nursing, 8(4), 26-35. Retrieved from http://ejournal.lucp.net/index.php/mjn/article/view/461

Eamin, A. K. M., Akanda, A., \& Haque, A. (2013). Newspaper reading habits of university graduate students in Bangladesh: A case study. International Journal of Research in Applied, Natural and Social Sciences (IMPACT: IJRANSS), 1(3), 1-8. Retrieved from http://impactjournals.us/download/archives/2-14-137534 0786-1. Applied-Newspaper-A.K.M. Eamin Ali Akanda.pdf

Ebele, U. F., \& Olofu, P. A. (2017). Study habit and its impact on secondary school students academic performance in biology in the Federal Capital Territory, Abuja. Educational Research and Reviews, 12(10), 583-588. doi: https://doi.org/10.5897/err2016.3117

Fitriah, D. (2017). Hubungan kemampuan membaca buku teks dan keterampilan berpikir kritis dengan hasil belajar pendidikan agama islam. Studia Didaktika: Jurnal IImiah Bidang Kependidikan, 11(1), 91-110. Retrieved from http://jurnal.uinbanten.ac.id/index.php/studiadidaktika/article/view/523

Goel, U. (2014). Comparative study of study habits in relation to academic achievement of senior secondry 
school students. GYANODAYA - The Journal of Progressive Education, 7(2), 18-25. doi: https://doi.org/ 10.5958/2229-4422.2014.00004.8

Irhas, M., Sumadi, S., \& Ridlo, S. (2018). The quantitative and qualitative analysis of students learning outcomes acording to student admission line of biology education program FMIPA Unnes. Journal of Biology Education, 7(1), 44-53. Retrieved from https://journal.unnes.ac.id/sju/index.php/ujbe/article/view/22086

Kaur, A., \& Pathania, R. (2015). Study habits and academic performance among late adolescents. Studies on Home and Community Science, 9(1), 33-35. doi: https://doi.org/10.1080/09737189.2015.11885430

Khong, R. W. L., Dunn, J. S., Lim, C.-M., \& Yap, W. S. P. (2016). Why do students attend lectures?: exploring justifications for attendance among undergraduate students from a British University in Asia. The Journal of Developing Areas, 50(5), 497-506. doi: https://doi.org/10.1353/jda.2016.0059

Kumaraswamy, S. (2019). Promotion of students participation and academic achievement in large classes: an action research report. International Journal of Instruction, 12(2), 369-382. doi: https://doi.org/10.29333 liji.2019.12224a

Magulod, G. C. (2019). Learning styles, study habits and academic performance of Filipino University students in applied science courses: implications for instruction. Journal of Technology and Science Education, 9(2), 184-198. doi: https://doi.org/10.3926/jotse.504

Manurung, T. M. S. (2017). Pengaruh motivasi dan perilaku belajar terhadap prestasi akademik mahasiswa. Jurnal Analisis Sistem Pendidikan Tinggi, 1(1), 17-26. Retrieved from http://journal.fdi.or.id/index.php/ jaspt/article/view/36

Monica, E. O. (2015). Influence of study habits on the academic achievement of students in home economics in junior secondary schools in enugu state. International Journal of Innovative Education Research, 3(4), 15-22. Retrieved from http://seahipaj.org/journals-ci/dec-2015/IJIER/full/IJIER-D-3-2015.pdf

Nadeem, N. A., Puja, J. A., \& Bhat, S. A. (2014). Study habits and academic achievement of kashmiri \& ladakhi adolescent girls: A comparative study. Turkish Online Journal of Distance Education, 15(2), 91-97. doi: https://doi.org/10.17718/tojde.22486

Numan, A., \& Hasan, S. S. (2017). Effect of study habits on test anxiety and academic achievement of undergraduate students. Journal of Research and Reflections in Education, 11(1), 1-14. Retrieved from http://ue.edu.pk/jrre/articles/1101001.pdf

Nurgiyantoro, B. (2004). Penilaian pembelajaran sastra berbasis kompetensi. DIKSI, 11(1), 91-116. Retrieved from https://core.ac.uk/download/pdf/11062749.pdf

Obadara, O. E., \& Olaopa, S. O. (2018). Social media utilisation, study habit and undergraduate students' academic performance in a university of education in Nigeria. Library Philosophy and Practice, 3(1), 115. Retrieved from https://digitalcommons.unl.edu/libphilprac/2082/

Ogunduyilemi, K. S. (2018). The relationship of undergraduate study habits with use of library resources in two universities in oyo state, Nigeria. Library Philosophy and Practice, 4(1), 1-28. Retrieved from https://digital commons.unl.edu/libphilprac/1862/

Rodrigo, V., Greenberg, D., \& Segal, D. (2014). Changes in reading habits by low literate adults through extensive reading. Reading in a Foreign Language, 26(1), 73-91. Retrieved from https://nflrc.hawaii.edu/ rfl/April2014/articles/rodrigo.pdf

Sakirudeen, A. O., \& Sanni, K. B. (2017). Study habits and academic performance of secondary school students in mathematic: A case study of selected secondary schools in uyo local education council. Research in Pedagogy, 7(2), 283-297. Retrieved from http://research.rs/no13/

Salvo, S. G., Welch, B., \& Shelton, K. (2019). African american males learning online: promoting academic achievement in higher education. Online Learning, 23(1), 22-36. doi: https://doi.org/10.24059/olj.v23i1. 1390

Sengul, B. T. (2017). A study on reading habits of social studies and history teachers in Turkey. Educational Research and Reviews, 12(10), 569-582. doi: https://doi.org/10.5897/err2017.3245

Sherafat, R., \& Murthy, C. G. V. (2016). A study of study habits and academic achievement among secondary and senior secondary school students of mysore city. The International Journal of Indian Psychology, 3(2), 162-170. Retrieved from http://oaji.net/articles/2016/1170-1453806341.pdf

Suharsimi, A. (2010). Prosedur penelitian : suatu pendekatan praktik (edisi revisi). In Jakarta: Rineka Cipta. Retrieved from http://onesearch.id/Record/IOS3504.libra-176346316000032

Üzüm, B., \& Pesen, A. (2018). Do the learner-centered approaches increase academic performance? effect of the layered curriculum on students' academic achievement in english lesson. International Journal of Instruction, 12(1), 1585-1608. doi: https://doi.org/10.29333/iji.2019.121101a 
Verma, A. (2016). A study of academic achievement among high school students in relation to their study habits. International Journal of Research in Humanities, Arts and Literature, 4(3), 75-88. Retrieved from http://www.impactjournals. us/archives?jname=11_2\&year=2016\&submit=Search\&page=2

Wulandari, S. (2014). Pengaruh motivasi belajar, perilaku belajar dan model pembelajaran kontruktivisme terhadap prestasi belajar mahasiswa kelas reguler fakultas ekonomi dan bisnis UIN Syarif Hidayatullah Jakarta. Esensi: Jurnal Bisnis Dan Manajemen, 4(1), 37-48. doi: https://doi.org/10.15408/ess.v4i1.1954 